\title{
Erratum to: The role of $S H P$ - 1 promoter 2 hypermethylation detection of lymph node micrometastasis in resectable stage I non-small cell lung cancer as a prognostic marker of disease recurrence
}

\author{
Chanida Vinayanuwattikun · Poonchavist Chantranuwat • \\ Virote Sriuranpong • Apiwat Mutirangura
}

Published online: 6 August 2013

(C) Japan Society of Clinical Oncology 2013

\section{Erratum to: Int J Clin Oncol}

\section{DOI 10.1007/s10147-013-0590-1}

This article was published with the given name and family name for each of the four authors in reverse order. The correct order, given name followed by family name, is shown in this erratum.

The online version of the original article can be found under doi:10.1007/s10147-013-0590-1.

C. Vinayanuwattikun $(\bowtie) \cdot$ V. Sriuranpong Division of Medical Oncology, Department of Medicine, Faculty of Medicine, Chulalongkorn University and The King

Chulalongkorn Memorial Hospital, Bangkok 10330, Thailand

e-mail: Chanida.Vi@chula.ac.th

P. Chantranuwat

Department of Pathology, Faculty of Medicine, Chulalongkorn

University and The King Chulalongkorn Memorial Hospital,

Bangkok 10330, Thailand

\section{A. Mutirangura}

Center of Excellence in Molecular Genetics of Cancer and

Human Diseases, Department of Anatomy, Faculty of Medicine,

Chulalongkorn University and The King Chulalongkorn

Memorial Hospital, Bangkok 10330, Thailand 